\title{
Universiteit
}

Leiden

The Netherlands

\section{History and Identity among the Hemshin}

Simonian, H.H.

\section{Citation}

Simonian, H. H. (2004). History and Identity among the Hemshin. Isim

Newsletter, 14(1), 24-25. Retrieved from https://hdl.handle.net/1887/16932

Version: $\quad$ Not Applicable (or Unknown)

License: $\quad$ Leiden University Non-exclusive license

Downloaded from: $\quad$ https://hdl.handle.net/1887/16932

Note: To cite this publication please use the final published version (if applicable). 


\section{History and Identity among the Hemshin}

HOVANN H. SIMONIAN The Hemshin or Hemshinli people live in the foothills and mountainous areas of the eastern Black Sea region of Turkey. The Hemshinli constitute a unique group, even within the context of the Eastern Black Sea region, which differs by its geography and ethnic and linguistic diversity from the rest of the country. One circumstance that sets the Hemshin apart from other groups of this region, such as the Lazi and the Georgians, is that they are divided into two communities almost oblivious to one another's existence, and separated by language, culture and territory. The districts of Camlıhemşin and Hemşin in the highlands of the province of Rize are the heartland of the western Hemshinli, or Bash-Hemshinli. This group is isolated by the exclusively Lazi district of Arhavi from the eastern Hemshinli, or Hopa-Hemshinli, who are mostly settled in the Hopa and Borcka districts of the Artvin province. Moreover, these two Hemshin groups are unaware of the existence of yet a third related community speaking a close if not identical dialect, the Christian Hamshen Armenians of Abkhazia and Krasnodar in Russia.

The Hemshinli constitute a truly fascinating phenomenon. They have preserved, centuries after their conversion to Islam, a sense of identity distinct from that of their neighbours, as well as, for part of them, their spoken Armenian dialect Homshetsma. By continuing to speak Armenian, they have reversed one of the more typical paradigms in the Ottoman Empire, whereby Armenian converts to Islam were assimilated completely into the surrounding Muslim environment, and Christian Armenians often became monolingual Turkishspeakers. The Armenian language did disappear around the middle of the nineteenth century among the Bash-Hemshinli, to be replaced by a local Turkish dialect containing a large number of Armenian loanwords, but it has survived to this day among the Hopa-Hemshinli. Furthermore, given the ongoing decline in the Diaspora of the use of the Armenian language, the ironic possibility that these Muslim villagers may well be the last speakers of Western Armenian cannot be excluded.

The Bash-Hemshinli approximately number between 15,000 and 23,000 individuals in the Rize province, while the Hopa-Hemshinli are estimated at around 25,000.1 To these figures must be added the dozen or so villages in the northwestern provinces of Düzce and Sakarya, settled by the Hemshinli during the last decades of the nineteenth century. Large communities of Hemshinli can also be found in regional centres such as Trabzon and Erzurum and in the large cities of western Turkey. A total figure of approximately 100,000 individuals for all of Turkey appears to be a realistic estimate.

In Nations and Nationalism, Ernest Gellner, using language as a criterion, gives a figure of approximately 8000 minority groups on earth Of these 8000 groups, he continues, barely one-tenth have developed "nationalisms," i.e. "the striving to make culture and polity congru ent," 2 or have elaborated any sort of ethnically based cultural and political agenda. The Hemshin, like their Lazi neighbours, clearly belong to the 90 percent of groups which have chosen not to mobilize on the basis of their ethnic identity. ${ }^{3}$ However, they have maintained a sense of collective identity, the distinction of which is recognized by their neighbours.

\section{Perceptions of history}

Historical sources agree that the Hemshinli are the descendants of Armenians who migrated to the Black Sea region or Pontos in the late eighth century. The district settled by these migrants came to be known as Hamamashen (i.e., built by Hamam), after Prince Hamam Amatuni, one of the leaders of the migration. With time, Hamamashen became Hamshen, and following Ottoman conquest in the late fifteenth century, Hemshin. In the seventeenth and eighteenth centuries, the Armenians of Hemshin converted to Islam. Various reasons have been given for conversion, including fiscal oppression, rise of Muslim intolerance vis-à-vis Christians following a series of Ottoman defeats at the hands of Rus-

sia, the breakdown of central authority in the late seventeenth century and the ensuing climate of anarchy when the region was at the mercy of warlords known as derebeys (valley lords). Islam is believed to have progressed from the coast up, with highland villages remaining Christian for a longer period than lowland ones. The religious context during the seventeenth and eighteenth centuries was, however, more complicated than that, as the boundary between Christians and Muslims in Hemshin was blurred by the existence of yet a third category composed of crypto-Christians known as Keskes (Armenian half-half). The crypto-Christians of Hemshin were reported until the late nineteenth century to attend church, secretly baptize their children, and continue to celebrate various Armenian religious feasts such as Vartevar (the Transfiguration of Christ) and Verapokhum (the Assumption). ${ }^{4}$

A majority of Hemshinli, however, reject any suggestion that they have Armenian ancestry, preferring the thesis presented to them by Turkish nationalist historians such as Fahrettin Kırzıoğlu. In its main lines, this revisionist version of Hemshin history argues that the Hemshinli are of pure Turkish stock and that they are the descendants of an authentic Turkish tribe. Historical and cultural links with Armenians are downplayed or simply denied, and the use of the Armenian language by the Hopa-Hemshinli is attributed to their coexistence with Armenians in a distant past. This narrative is basically an extension to the Hemshinli of historical and linguistic theories, such as the Turkish Historical Thesis and the extravagant "sun language theory" (güneş-dil teorisi), which have been created and supported by the Turkish Republic since the early 1930 s as an integral part of the nation- and statebuilding process. While Kırzıoğlu has certainly been the chief and most famous proponent of the Turkish state version of Hemshin history, it was his predecessor M. Riza, who stated in a 1933 book that the Hemshinli were "Hittite Turks"" and that after speaking Armenian for a while, "they now know no other language than Turkish."5

The popularity of Turkish nationalist theories is obviously linked to the Armenian-Turkish antagonism and to the fact that it is socially more acceptable to claim Turkic ancestors from Central Asia than Armenian ones in the modern Turkish Republic. Yet, the preference of the Hemshinli for this thesis also has deeper roots that go back to Ottoman times. In the pre-national context of the Ottoman Empire, people identified themselves in terms of their membership in a particular religious community, or millet. Thus, being "Armenian" prior to the import of the European idea of nation to the Ottoman Empire meant belonging to the Armenian Apostolic Church and the millet it composed. Leaving the Armenian Church to join another Christian denomination 


\section{Identity \& Culture}

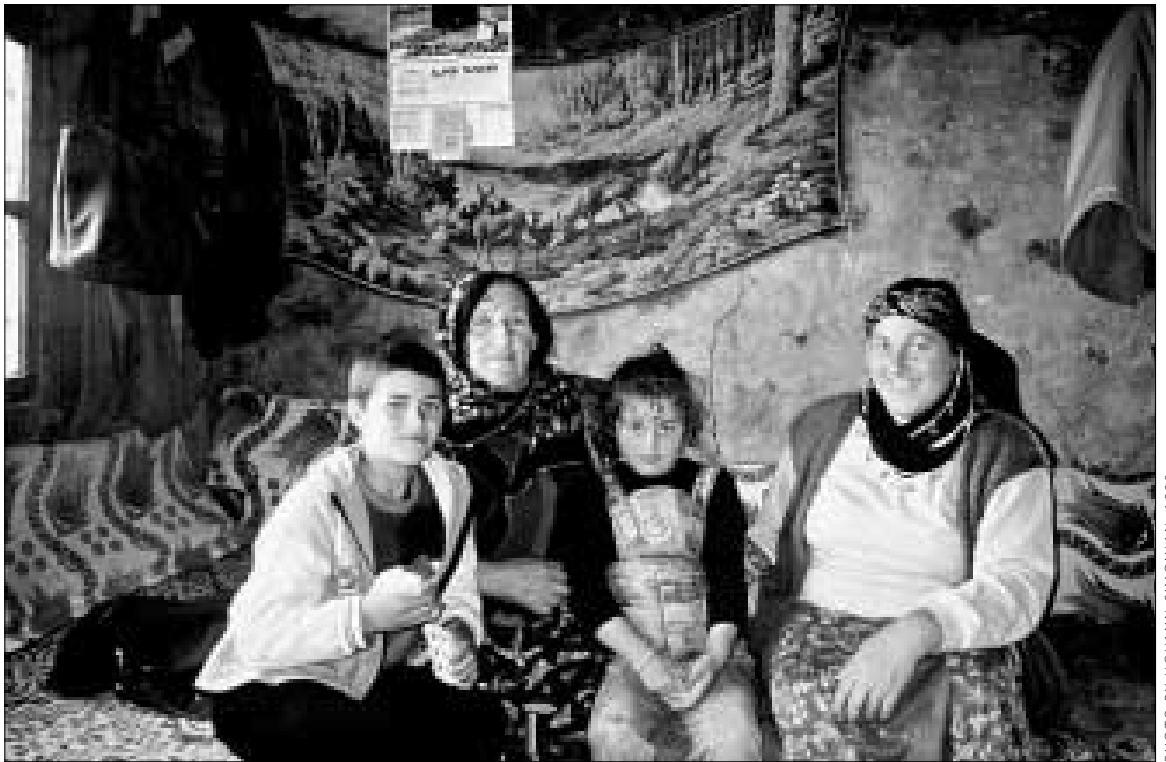

Hemshin family,

Tirovit yayla

or Islam also meant that one stopped being part of the Armenian "nation." "Armenian" was used interchangeably with "Christian," and "Turk" with "Muslim" - and continues to be done so to this day by most of Turkey's rural population. That one could possibly be "Turk" and "Christian" or "Armenian" and "Muslim" was-and still is to most of Turkey's population-a concept that was simply beyond the grasp of most of the Ottoman Empire's inhabitants; an anomaly.

\section{Identity issues}

The estrangement between Hemshinli and Armenians is best shown in the fascinating anecdote reported by the famous French linguist Georges Dumézil, who studied the Armenian dialect of Hemshin and published a series of articles on the topic in the 1960s. The young Hemshinli with whom Dumézil worked had no idea whatsoever that he spoke Armenian. He had only noticed when going at the beach in Istanbul that there were people speaking a language he could understand (i.e., Istanbul Armenians), yet he had no idea why, as they were not from his village or region.

Answers on ethnic origins among the Hemshinli may well vary according to gender, place of residence, age, or location of discussion What often appears is a reverse correlation between wealth and influence on the one hand and admission to Armenian origins on the other Thus, older women living in a village of Çamlihemşin or Hopa will be more likely to admit to their Armenian ancestry than middle-aged businessmen residing in Ankara, who are more likely to staunchly reject any Armenian connection. Younger people, meanwhile, appear both confused and curious about their origins. In some cases, the Hemshinli who admit to some sort of Armenian ancestry will mention that the family founder was a migrant to the area, usually from Central Asia, who married within the Hemshinli community, and gradually assimilated. The same is visible among the Laz. It could be true, but it is a way of "saving" one's family past while admitting the painful "truth" for the rest of the group. In conversations with Hemshinli individuals who admitted to Armenian origins, there appeared to be two or three levels of perception of "Armenians": one's ancestors before conversion, the Hemshinli who remained Christians prior to WWI, and modern-day Armenians, from the Diaspora or the republic of Armenia.

While opinions on origins vary, there is a clear consciousness of group identity, including the notion of Hemşinlilik, i.e., to be Hemshin. This sense of community is expressed in the following statement from a Hemshinli periodical published in Ankara: "We, Hemshinli, are people who are spread out in all directions of Anatolia. But the longing for Hemşin inside us binds us strongly together." ${ }^{7}$ The separation of Hemshinli into Bash-Hemshinli and Hopa-Hemshinli means there are actually two distinct group identities. The two groups do not mingle in the large cities of western Turkey and maintain separate associations.
The traditional head-gear (puşi) used among Bash-Hemshinli is unknown among the Hopa-Hemshinli. The western, or Bash-Hemshinli, continue to celebrate Vartevar in their summer pastures (yayla) - even if the religious meaning of the feast appears to have long been lost on them-and have generally maintained more Armenian traditions than the Hopa-Hemshinli. However, it is more the continued use of Homshetsma, the Armenian dialect of Hamshen, by the HopaHemshinli than the preservation of Armenian festivals by the BashHemshinli that has attracted the attention of outsiders to the Hemshinli population. The continued use of Homshetsma by the HopaHemshinli is also believed to be one of the reasons for the separation between the two groups, as the Bash-Hemshinli prefer not be associated with Armenian-speakers.

It is difficult to assert what the future holds for a small group like the Hemshinli. Assimilation represents a clear danger for the survival of the group. It is interesting to note in this context that the verb "assimilate" has been adopted into Turkish and that minority groups like the Lazi and the Hemshin are often described as having been assimilated (assimiley olmus). ${ }^{8}$ The rural exodus has emptied most Hemshinli villages-particularly in Bash-Hemshin-leaving only elderly people to live yearround in their native district. Some Hopa-Hemshinli families are not teaching their children Homshetsma anymore, and the Turkish dialect used in Bash-Hemshin, which contains numerous Armenian loan-words, is dying. However, many young Hemshinli, including those born in the large cities of western Turkey, show a strong in terest in preserving the culture of their ancestors. The day of doom has not arrived yet for the Hemshinli. They have not "awakened" as a nation-and have certainly no desire to-but neither have they allowed their distinct cultural identity to disappear.

Hovann H. Simonian is a Ph.D. candidate in the department of Political Science at the University of Southern California (USC). E-mail:Hovanns@aol.com
Notes

1. Rüdiger Benninghaus, "Zur Herkunft und Identität der Hemșinli," in Ethnic Groups in the Republic of Turkey, ed. Peter Alford Andrews (Wiesbaden: Dr. Ludwig Reichert Verlag, 1989), 477.

2. Ernest Gellner, Nations and Nationalism (Ithaca, New York: Cornell University Press, 1983), 43-50.

3. Chris Hann, "Ethnicity, Language and Politics in North-east Turkey," in The Politics of Ethnic Consciousness, ed. Cora Govers and Hans Vermeulen (London: Macmillan, 1997), 122.

4. For a detailed history of Hemshin, see the forthcoming volume, The Hemshin, ed. Hovann Simonian, to be published by Curzon-Routledge in 2004

5. M. Rıza, Benlik ve Dilbirliǧimiz, 2nd ed. (Ankara: Türk Kültürünü Araștırma Enstitüsü, 1982), 35-36. First published in 1933. 6. Georges Dumézil, "Notes sur le Parler d'un Arménien Musulman d'Ardala," Revue des Études Arméniennes n.s. 2 (1965), 135-42.

7. Benninghaus, $487 \mathrm{n} 71$.

8. Ildikó Bellér-Hann and Chris Hann, Turkish Region: State, Market and Social Identities on the East Black Sea Coast (Santa Fe, New Mexico: School of American Research Press, 2001), 204. 